Station on Disco Island, moreover agree with me that there is no real evidence, either archæological or otherwise, for the popularly supposed serious deterioration of climate sinee the time of the Nordic colonization.

What was probably the strongest suggestion of such a change resulted from the discovery of the coffins of some buried Norsemen permeated by roots of plants but all frozen in summer ${ }^{9}$; but that was only in one place far out on the exposed ocean coast and in a bad year and other quite unustial circumstances, as the late Fridtjof Nansen quickly pointed out in objecting to this suggestion; moreover, the presence or absence of frozen soil conditions depends on a number of factors of which aerial temperature is only one ${ }^{10}$. That the climate may have become somewhat drier and a very little cooler since the advent of the Norsemen seems quite possible, and indeed just around Eric the Red's estate at Qagssiarssuk where the birch 'trees' were extensively cleared by the Norsemen they have failed to reappear even in the 400-500 years since the dying out of the colony. But there is no evidence of a change great enough to have been, at the very most, more than one factor contributing in some degree to the downfall of their once flourishing civilization.

Thus the peat deposits show no signs of any important change in the summer temperature since long before the advent of the Norsemen ${ }^{11}$, while even if the climate has become drier the conditions are still damp enough to support over large areas in this district luxuriant grassy herb communities that afford some of the best summer pasturage I have ever seen ! Moreover the outlawed Eric, in what has wittily been termed 'the first real-estate venture', called the country Groenaland 'the green land' merely in order that he might the more easily attract colonists from Iceland ${ }^{12}-$ which suggests that the notoriously inhospitable aspect of the coast is no mere present-day phenomenon. Finally, and perhaps most significantly of all, the tree and bush communities in some places show to this day what is with little doubt the same delimitation as they were given by cutting by the Norsemen and grazing by their domestic animals. It is inconceivable that the extremely fine equilibrium existing between these 'higher' communities on one hand and the luxuriant alternating patches of grass and herbs on the other could have been maintained in the face of any appreciable climatic vagaries, much less a profound change; while even if this remarkable community delimitation can only with fair certainty be stated to date from the final disappearance of the Norsemen, it seems highly probable that it is the result of long lasting biotic impress and hence dates from well before that time. Even the temperature of the earlier warm period, which presumably corresponded to the sub-boreal of Europe, may have been only slightly above that of the present day, for no evidence has yet been found of the occurrence in Greenland in post-glacial times of any plant formation or species which does not live there now.

Since the above was written Prof. Jessen has informed me (1) that he has found plentiful fruits of Betula publescens s.l. in peat layers from south-west Greenland that were laid down long before the advent of the Norsemen, which finally proves that the plant is indigenous; and (2) that from the experience of many deep borings which he made in the summer of 1926 in the Julianehaab district it was obvious that ice was quite absent from the ground.

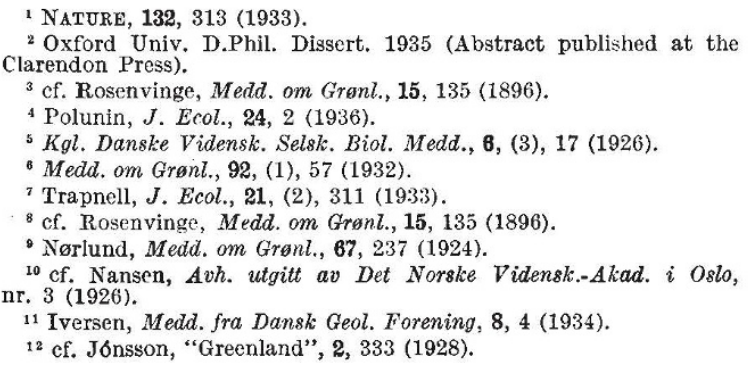

\title{
The Cyclol Hypothesis and the 'Globular' Proteins
}

$\mathrm{D}^{\mathrm{r}}$ R. D. M. WRINCH has extended the cyclol theory of protein structure to account for the existence of space-enclosing or 'globular' molecules (Proc. Roy. Soc., A, 161, 505 ; 1937).

The cyclol theory showed that a molecular fabric could be formed on the basis of the polypeptide theory by assuming that the peptides did not lie fully extended but underwent rotation at the bonds to form hexagonal structures. A series of these containing $2,6,18 \ldots .18+24 n$ residues can form closed systems of regular geometrical form with three-way symmetry. The second member of this series, called 'cyclol 6', forms the basis of the 'cyclol fabric'. Other members of the series could, if it were desired, be used as the basis of geometrically regular two-dimensional fabrics.

Any theory of the structure of three-dimensional molecules containing several thousand atoms must take into account the mathematical possibilities of distributing these in space in such a way that the resulting model will account for the known chemical and physical properties of the substance in question. The cyclol fabric can be folded along certain welldefined lines to form space-enclosing models of regular geometrical form, without violating any of the funda. mental requirements of the cyclol fabric; for ex. ample, truncated tetrahedra can be formed by bend. ing round the cyclol fabric without any distortion of the cyclol net. The truncated tetrahedra form a series which contain 72,288 . . $72 n^{2}$ residues. These tetrahedral models, like the original 'cyclol 6', allow for polymerization, so that one, two or more of them can be brought together by apposition of their plane faces to form a series of polymers.

The model containing 288 residues is of great interest for it would have a molecular weight approximating to 35,000 , which Svedberg has found as a basic number for the molecular weights of globular proteins. For example, insulin and egg albumin (which on the cyclol theory consist of 288 residues per molecule) have molecular weights of approximately 35,000 , while various other proteins have molecular 
weights approximating to $35,000 \times 1,2,4$ or 8 . Many of these under conditions of varying $p \mathrm{H}$ can break up reversibly into segments which are simple submultiples of the original molecular weight. It is also interesting to notice that Bergmann and Niemann (since the above prediction) state that the chemical analysis of egg albumin enables them to deduce that this molecule consists of exactly 288 residues $(J$. Biol. Chem., 118, 301 ; 1937).

A series of models based on the truncated tetrahedron formed from the cyclol fabric and simple polymers of this, thus accounts satisfactorily for the type of molecular weight series found in some 'globular' proteins, namely, simple multiples of a basic unit of 35,000 .

\section{The Problem of Leisure}

$\mathrm{W}^{\mathrm{n}}$ have not infrequently insisted upon the problem of leisure as one of growing importance, and have emphasized the inevitable effects of the application of science to industrial processeseffects which have been put under the heading of 'technological unemployment'. As the machine lessens the volume of toil required from men and women, our social organization must be adapted to give the new services which will be demanded of it. Already the move towards a reduction in working hours is apparent and must bring with it a corresponding increase in the hours of leisure. How will that leisure be used?

The widespread interest in the possible answers to that question was shown on November 18 when more than two hundred bodies were represented at a conference arranged by the National Institute of Industrial Psychology and the British Institute of Adult Education. The problem of leisure was the problem which attracted that very large audience, and it was finally decided to set up a committee representative of bodies willing to co-operate in the carrying out of what might be called our first survey of leisure. It will consist in the first place of an investigation of the opportunities for leisure, for, clearly, any such survey will fail in its purpose if it neglect factors such as housing conditions, transport facilities, the extent to which poverty debars from participation in recreation, and other similar considerations.

The purpose of any report which may be drawn up as a result of the investigation will not be to interfere with or supplant the work of bodies already engaged in work affecting leisure activities, but to assist them.

The survey will be on broad lines and will recognize that, while many leisure pursuits require organization, resentment would arise from anything suggestive of coercion, patronage or intrusion on individual privacy.

The present suggestion is that the investigators should base their report upon a first-hand examination of the facts in certain districts which would be selected so far as possible as being typical of prevalent conditions. The following list of districts has been compiled as one where investigations would doubtless be most profitable: a town of varied districts where the factories, dwellings and recreational facilities are within easy reach of one another ; a district where the workers' dwellings and their recreational facilities are distant from their work ; a developing district where the conditions of work and leisure have been planned, but where the population has grown up without local civic conditions; a developing, but unplanned, district; a district where varied industries are scattered amid rural surroundings; and a popular holiday resort, with special reference to the increasing extension of the holiday season beyond the summer months. The increase of holidays with pay, the raising of the age of entry, and the lowering of the age of exit, from industry and the incidence of shift work are all factors which must be taken into consideration as the investigation proceeds. Duplication of effort will be avoided and investigators will be asked to distinguish carefully between the collection of fact, the collection of opinion and their own conclusions.

\section{Science News a Century Ago}

\section{Anniversary Meeting of the Royal Society}

AT the anniversary meeting of the Royal Society on November 30, 1837, the president, H.R.H. the Duke of Sussex, being prevented from attending by illness, his address was read by Francis Baily. In the report of the Council for the year, it was said: "The principal business of public interest which has occupied the attention of the Council relates to the extension of accurate magnetical and meteorological observations in different parts of the world.

"A communication having been made by Lieut. William Denison, of the Royal Engineers, of a proposal from General Mulcaster, Inspector-General of Fortifications, that the officers of engineers generally should be employed, under the direction of the Royal Society, in promoting the advancement of science, by carrying on connected series of observations relating to Natural History, Meteorology, Magnetism and other branches of physical science, and suggesting an application to Government for a grant of funds necessary for effecting so desirable an object; a Committee was appointed to consider the proposed measure, and of the means to carry into effect the recommendations contained in the letter of Baron Von Humboldt addressed in April last to the President. Conformably with the report the Council fixed on the ten following places, namely, Gibraltar, Corfu, Ceylon, Hobart Town, Jamaica, Barbados, Newfoundland, Toronto, Bagdad and the Cape of Good Hope as being the most eligible for carrying on magnetic observations . . . these places being permanent stations where officers of engineers and clerks are always to be found." A grant of $£ 500$ for instruments was afterwards obtained from the Government.

\section{Award of Two Copley Medals}

THE report of the Council also referred to the award of the various medals, two Copley Medals being awarded on this occasion, one to A. C. Becquerel and the other to J.F. Daniell. The award to Becquerel was "particularly for the production of crystals of Metallic Sulphurets and of Sulphur; by the longcontinued action of electricity of very low tension. In the memoirs particularly referred to by the Council he has especially in view to explain, by the agency of electricity of very low tension, continued for an indefinite time, the occurrence of erystalised substances in mineral veins. By his work $\mathrm{Mr}$. 